\title{
On the functional significance of masking behaviour in sea urchins - an experiment with Paracentrotus lividus
}

\author{
Heinz Richner ${ }^{1,2, *}$, Manfred Milinski ${ }^{1,3}$ \\ ${ }^{1}$ Station Biologique Arago, 66650 Banyuls-sur-Mer, France \\ ${ }^{2}$ Department of Zoology, University of Bern, 3032 Hinterkappelen, Switzerland \\ ${ }^{3}$ Department of Evolutionary Ecology, Max Planck Institute of Limnology, 24306 Plön, Germany
}

\begin{abstract}
Much literature in marine biology describes the extraordinary behaviour of sea urchins, e.g., Paracentrotus lividus, who cover their body with shells, stones and debris. The function of this strange behaviour, described as 'masking', is still a puzzle. Our experiment shows that sea urchins are loaded with more mussel shells when the delicate apical openings of their water vascular system which powers all their movements, are in danger of being occluded by floating sand. 'Masking' shells appear to function as an umbrella against floating particles.
\end{abstract}

KEY WORDS: Masking behaviour $\cdot$ Cleaning $\cdot$ Paracentrotus lividus

Resale or republication not permitted without written consent of the publisher

Several species of sea urchins, e.g., Paracentrotus lividus, which is common in the Mediterranean and the Atlantic Ocean, actively cover their body with bivalve shells (see Fig. 1a), gastropod shells, stones, pebbles, algal thalli, leaves, and sea urchin tests (e.g., Zavodnik 1987, Ivesa 1998); even cherry and peach stones, coins, banknotes, and pieces of glass and plastic have been listed (Zavodnik 1987). Textbooks (e.g., Luther \& Fiedler 1961, Riedl 1983), which describe this behaviour as 'masking', suggest that the shells and other objects may protect the sea urchin from harmful UV light. This is unlikely, however, since UV light is strongly attenuated with depth, e.g., the effect of sunlight is reduced to $50 \%$ at $1 \mathrm{~m}$ below the surface (Levington 1995). In addition, sea urchins living at greater depths are just as likely to be covered with shells as the ones closer to the surface (Ivesa 1998, authors' pers. obs.).

Here we report on an experiment performed to test our hypothesis that the covering behaviour of sea

*E-mail: heinz.richner@esh.unibe.ch urchins serves to protect the animal from deposition of mud, sand and other dirt. In fact, some of the sea urchins' vital organs, such as the sexual system and the internal water exchange system, drain on its upper side, partly through the fine sieve-like madreporite vulnerable to congestion. Furthermore, hundreds of small pedicillariae, which have tiny suckers and pliers on the end, are in constant action to clean the sea urchin's surface (Hayward \& Ryland 1995, Levington 1995). Thus, active covering with shells may be an accompanying preventive mechanism.

Methods. We collected shell-covered sea urchins Paracentrotus lividus $200 \mathrm{~m}$ off the harbour area of Banyuls-sur-Mer, France. 'Masking' shells were removed from 54 sea urchins, which were individually placed into aquaria $(30 \times 30 \mathrm{~cm})$ with fresh seawater (water level $13 \mathrm{~cm}$ ). Experiments were performed in a cellar room (of the Station Biologique Arago), which was illuminated by fluorescent tubes from the ceiling. We placed a size- and species-matched collection of 5 mussel shells (collected from sea urchins in the field) in a half-circle $5 \mathrm{~cm}$ away from each urchin. Within a total of 27 sets, each containing 2 size-matched sea urchins, individuals were randomly assigned to 1 of 2 treatment groups. In one group, we slowly poured a quarter of a teaspoon of seawater-suspended sand over each sea urchin. In the other group, sea urchins were treated with clean seawater only. We determined the number of shells loaded by the sea urchins 10 min after they had been treated. The diameter of the body, not including spines, was $7.0 \pm 0.2 \mathrm{~cm}$ (mean $\pm \mathrm{SE}$ ) in the sand treatment and $7.0 \pm 0.1 \mathrm{~cm}$ in the control treatment. Shell loading within the 27 sets was analysed by means of a repeated-measures ANOVA with body size defined as a covariate.

Results. In accordance with our hypothesis the sea urchins treated with water-suspended sand covered 


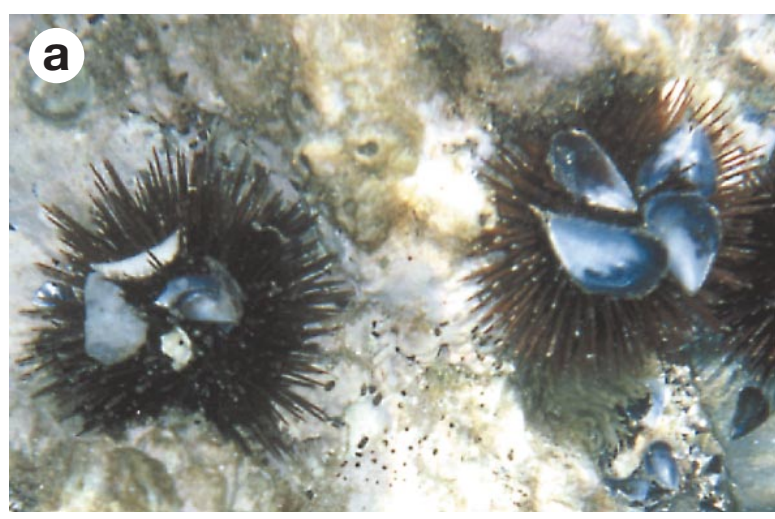

b

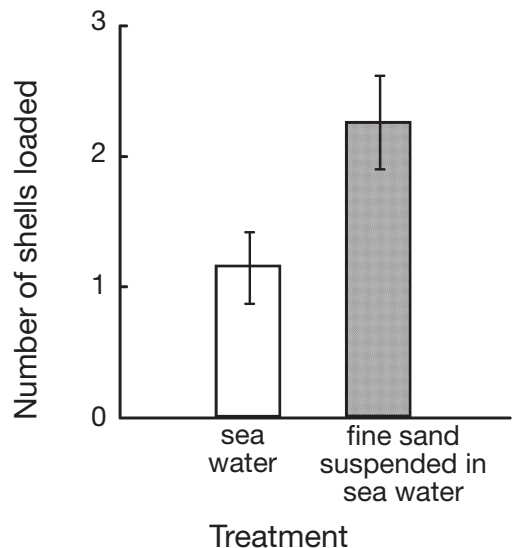

Fig. 1. Paracentrotus lividus. (a) Sea urchins 'masked' with mussel shells in the field. (b) Mean $( \pm \mathrm{SE})$ number of shells loaded by the urchins 10 min after being treated with either seawater or seawater-suspended sand

themselves with a significantly higher number of shells than did the ones that were treated with clean seawater only (Fig. $1 \mathrm{~b}$, repeated measures ANOVA, $F_{1,25}=$ 5.92, $\mathrm{p}=0.023)$. Furthermore, larger sea urchins loaded a higher number of shells $\left(F_{1,25}=5.65, \mathrm{p}=\right.$ 0.025).

Discussion. The sea urchins must have somehow measured the amount of sand drifting over their body, because the rate at which they covered themselves with mussel shells significantly increased in the 'sand' treat-

Editorial responsibility: Otto Kinne (Editor), Oldendorf/Luhe, Germany ment group. Larger urchins loaded more shells, probably because the shells offered in all trials were of a similar size and thus more of them were needed to cover their body surface. Our experimental finding that the sea urchins' response to drifting sand functions to protect the body from floating particles does not exclude, however, the possibility that the 'masking' behaviour is also performed for other reasons which may differ in other parts of Paracentrotus lividus' distribution.

The conditional response suggests that a function of 'masking' is the protection from sand. Under natural conditions, floating particles might obstruct the sea urchins' sophisticated apical in- and outlet systems. This flexible 'masking' behaviour seems efficient because the urchin would otherwise have to remove the sand particle-by-particle with its pedicillariae. 'Masking' behaviour appears to be a preventive mechanism because sea urchins that had been treated only with clean seawater covered themselves with shells; however, fewer shells were used. The fact that the response is conditional suggests that loading shells must have a cost, the nature of which needs further investigation.

Acknowledgements. We thank the people at Station Biologique Arago for their hospitality.

\section{LITERATURE CITED}

Hayward PJ, Ryland JS (1995) The marine fauna of the British Isles and North-West Europe. Clarendon Press, Oxford

Ivesa L (1998) Sea urchin Paracentrotus lividus (Lamarck, 1816) (Echinodermata, Echinoidea) population of the southern Istria (Adriatic Sea). Period Biol 100:93-99

Levington JS (1995) Marine biology. Oxford University Press, New York

Luther W, Fiedler K (1961) Die Unterwasserfauna der Mittelmeerküsten. Paul Parey, Berlin

Riedl R (1983) Fauna und Flora des Mittelmeeres. Paul Parey, Berlin

Zavodnik D (1987) Synopsis on the sea urchin Paracentrotus lividus (Lamarck, 1816) in the Adriatic Sea. In: Boudouresque CF (ed) Colloque international sur Paracentrotus lividus et les oursins comestibles. GIS Posidonie, Marseille, p 221-240

Submitted: May 3, 2000; Accepted: July 18, 2000

Proofs received from author(s): September 19, 2000 